\title{
ISOLATION AND MOLECULAR IDENTIFICATION OF ENDOPHYTIC BACTERIA OF CLOVE LEAF (Syzygium aromaticum L) AND MECHANISM OF ACTION ANTIBACTERIAL
}

\author{
Sogandi ${ }^{1)}$, Irviyani ${ }^{1)}$ dan Usep Suhendar ${ }^{2 *}$ \\ ${ }^{1)}$ Jurusan Farmasi, Fakultas Farmasi, Universitas 17 Agustus 1945 Jakarta, Jl. Sunter Permai Raya, \\ DKI Jakarta, 14350, Indonesia ; \\ ${ }^{2)}$ Program Studi Farmasi, Fakultas Matematika dan Ilmu Pengetahuan Alam, Universitas Pakuan, J1 \\ Pakuan No 1, Kota Bogor, 16129, Indonesia;
}

\section{ARTICLE INFO}

Article history:

Received 21 Jul 2021,

Revised 18 Jan 2022,

Accepted 25 Jan 2022

Available online 28 Jan 2022

Keywords:

$$
\begin{array}{ll}
\checkmark & \text { Antibacterial } \\
\checkmark & \text { Endophytic } \\
\checkmark & \text { Clove Leaves } \\
\checkmark & \text { Bioactive } \\
\checkmark & \text { Syzygium }
\end{array}
$$$$
\text { aromaticum }
$$

*corresponding author: usep.suhendar@unpak.ac.id

https://doi.org/10.31938/jsn.v $\underline{12 \mathrm{i} 1.326}$

\begin{abstract}
Endophytic bacteria are microorganisms that live in plant parts. Endophytic bacteria from clove (Syzygium aromaticum L.) leaves with antibacterial activity are rarely reported. Therefore, this study aims to isolate endophytic bacteria from clove leaves (Syzygium aromaticum L.), screen and determine potential endophytic bacteria as antibacterial compounds, identify molecularly with $16 \mathrm{~S}$ rRNA, analyze bacterial growth curves and detect bioactive compounds produced by potential bacteria. Endophytic bacteria were isolated as many as 7 pure isolates including IRV1, IRV2, IRV3, IRV4, IRV5, IRV6, IRV7. IRV3 isolates showed the most dominant activity in inhibiting the growth of test bacteria and as the most potential producer of antibacterial compounds. Molecular identification with PCR (polymerase chain reaction) amplification in the 16S rRNA gene showed IRV3 isolate as Staphylococcus $s p$. with a 99\% similarity value. Besides, the results of GCMS analysis of secondary metabolites of IRV3 isolates showed pyrazine content as a dominant compound, which has been known as a bioactive compound in inhibiting bacterial growth. Therefore, the results of this study revealed that IRV3 isolates that were successfully isolated and identified would be able to contribute to further research to find new antibiotic sources.
\end{abstract}

\section{ABSTRAK \\ Isolasi dan Identifikasi Molekuler Bakteri Endofit Daun Cengkeh (Syzigium aromaticum L) dan Mekanisme Aksinya Sebagai Antibakteri}

Bakteri endofit adalah mikroorganisme yang hidup di dalam bagian tanaman. Bakteri endofit dari daun cengkeh (Syzygium aromaticum L.) dengan aktivitas antibakteri masih jarang dilaporkan. Oleh karena itu, penelitian ini bertujuan untuk mengisolasi bakteri endofit dari daun cengkeh (Syzygium aromaticum L.), skrining dan menentukan bakteri endofit potensial sebagai penghasil senyawa antibakteri, mengidentifikasi secara molekuler dengan 16S rRNA, menganalisis kurva pertumbuhan bakteri dan mendeteksi senyawa bioaktif yang diproduksi oleh bakteri potensial. Bakteri endofit yang berhasil diisolasi sebanyak 7 isolat murni diantaranya IRV1, IRV2, IRV3, IRV4, IRV5, IRV6, IRV7. Isolat IRV3 menunjukkan aktivitas yang paling dominan dalam menghambat pertumbuhan bakteri uji dan sebagai penghasil senyawa antibakteri yang paling potensial. Identifikasi molekuler dengan amplifikasi PCR (polymerase chain reaction) pada gen 16S rRNA menunjukkan isolat IRV3 sebagai Staphylococcus $s p$. dengan nilai similaritas $99 \%$. Selain itu, hasil analisis GCMS dari metabolit sekunder isolat IRV3 menunjukkan kandungan pirazin sebagai senyawa dominan, yang telah dikenal sebagai senyawa bioaktif dalam menghambat pertumbuhan bakteri. Oleh karena itu, hasil penelitian ini mengungkapkan bahwa isolate IRV3 yang berhasil diisolasi dan diidentifikasi akan dapat berkontribusi pada penelitian lebih lanjut untuk menemukan sumber antibiotik baru.

Kata kunci: antibakteri, endofit, daun cengkeh, bioaktif, Syzigium aromaticum 


\section{PENDAHULUAN}

Sumber daya alam Indonesia memiliki beragam tanaman yang dapat digunakan sebagai sumber untuk pengobatan. Sumber daya alam telah menyediakan industri farmasi dengan sumber senyawa kimia yang paling penting, dan hingga $40 \%$ dari obat modern berasal dari sumber alam (Jassim \& Naji, 2003). Ini menunjukkan peran terapeutik potensial tanaman di bidang kesehatan (health) (Barthwal et al.,2008). Tanaman memiliki aktivitas antioksidan yang mengandung senyawa metabolit sekunder (Asif, 2015). Senyawa kimia yang digunakan sebagai antioksidan alami seperti copherol, asam askorbat, dan flavonoid telah banyak dipelajari (Birch et al., 2001). Tanaman cengkeh (Syzygium aromaticum L) merupakan tanaman yang telah banyak digunakan oleh masyarakat di Indonesia. Cengkeh memiliki kandungan minyak sebagai hasil produk olahan dari tanaman cengkeh (Syzygium aromaticum L). Produk olahan dari tanaman cengkeh memiliki senyawa eugenol. Karakterisasi dilakukan dengan metode GC-MS terhadap senyawa aktif yang terdapat pada produk olahan utama minyak cengkeh tersebut, menyimpulkan bahwa senyawa penting yang diperoleh dari produk olahan tanaman cengkeh memiliki kesamaan dengan senyawa eugenol dengan tingkat kesamaan sebesar $98 \%$. Senyawa kimia tersebut memiliki aktivitas sebagai anti-mikrobial.

Bakteri endofit mampu hidup bersama secara simbiosis dalam jaringan tanpa menyebabkan efek negatif bagi tanaman. Hubungan antara tanaman dan bakteri endofit merupakan simbiosis mutualisme yaitu menghasilkan senyawa bioaktif yang sama pada tanaman inangnya (Barbara \&christine, 2006). Mikroorganisme endofit merupakan mikroorganisme yang dapat diisolasi dari seluruh bagian tanaman (Larran et al., 2016). Tanaman dapat bersimbiosis dengan mikroba endofit yang mampu menghasilkan senyawa kimia yang mirip dengan senyawa kimia yang dihasilkan oleh tanaman inangnya. Kemampuan mikroba endofit untuk menghasilkan senyawa kimia sesuai dengan tanaman inangnya menjadi peluang besar yang dapat digunakan untuk pencarian dan sekaligus memproduksi senyawa kimia yang dapat digunakan sebagai obat yang diperoleh dari produksi mikroba endofit. Jadi, jika endofit yang diperoleh dari tanaman dapat menghasilkan senyawa kimia dalam jumlah yang besar dan tidak perlu mengurangi tanaman inanngnya untuk diambil sebagai bahan simplisia. Dengan mengolahnya menjadi simplisia tentu mungkin membutuhkan waktu yang lama dalam setiap proses pemisahan senyawa kimia (Radji, 2005).

Berdasarkan sifat bakteri endofit, bakteri endofit melawan mikroba patogen dengan mengganggu metabolisme sel, menghambat sintesis dinding sel, mengganggu permeabilitas, dan menghambat sintesis protein dalam sel (Syarmalina, 2008). Bakteri endofit ini ditemukan di berbagai bagian jaringan tanaman, tetapi tidak menyebabkan penyakit. Bakteri endofit ini mampu hidup saling tidak merugikan, dalam hal ini bakteri endofit memperoleh nutrisi dari hasil metabolisme tanaman dan melindungi tanaman dari berbagai kondisi biotik dan abiotik. Sebaliknya, tanaman mendapatkan derivat nutrisi dan senyawa aktif selama hidup bersimbiosis tersebut (Tanaka et al., 1999). Berdasarkan latar belakang ini, penelitian dilakukan untuk mengisolasi dan mengidentifikasi bakteri endofit molekuler dari daun cengkeh (Syzygium aromaticum $\mathrm{L}$ ), memperlambat pertumbuhan bakteri Staphylococcus aureus ATCC 6538 dan Escherichia coli ATCC 8739.

\section{BAHAN DAN METODE}

\section{Bahan dan Alat}

Bahan-Bahan yang digunakan dalam penelitian ini adalah daun cengkeh (Syzygium aromaticum L), Tryptone Soy Agar (TSA) Merk, Tryptic Soy Broth (TSB) Merk, $\mathrm{NaClO}_{3}$, Buffer Posfat, etanol 70\%, pelarut n-butanol, n-heksana, etil asetat, Ampicillin $10 \mathrm{mg} / \mathrm{ml}$, nystatin, aqua dest, Staphylococcus aureus ATCC 6538 dan Escherichia coli ATCC 8739. Alat yang digunakan dalam penelitian ini termasuk Laminar Air Flow (LAF), sentrifugal, UV-VIS Spectrophotometer, Polymerase Chain Reaction (PCR), Gas Chromatography-Mass Spectrometer (GC-MS) Agilent Technologies 7890, perangkat lunak ChromasPro, DNA MAN v9.0, MEGA 7.0.

\section{Metode \\ Isolasi Bakteri Endofit Daun Cengkeh (Syzigium aromaticum $\mathrm{L}$ ) \\ Dalam penelitian ini, daun cengkeh} (Syzygium aromaticum L.) dengan kondisi 
karakteristik baik dan dari tengah batang permukaan disterilkan mengikuti protokol Sogandi et al.,(2019) dengan modifikasi. Pertama, daun segar dicuci dengan air mengalir, kemudian permukaan disterilkan dengan $2 \%$ natrium hipoklorit selama 5 menit dan dicuci dengan air suling setidaknya tiga kali. Sampel daun cengkeh akhirnya dicuci dengan etanol $70 \%$ dan kemudian diuapkan. Setelah penguapan etanol dari permukaan daun cengkeh, daun cengkeh dipotong menjadi potongan-potongan kecil $(1 \mathrm{x} 1 \mathrm{~cm})$ dan ditempatkan pada permukaan piring Tryptone Soy Agar (TSA) yang dilengkapi dengan nystatin incrusted pada suhu $37^{\circ}$ C. Piring diperiksa setiap hari setelah injeksi, dan setelah tiga hari inkubasi, bakteri endofit dari sampel daun cengkeh diambil tujuh koloni dengan morfologi terbaik, dimurnikan dengan isolat budaya untuk memastikan bahwa itu benar-benar koloni tunggal, isolat bernomor adalah Irv1, Irv2, Irv3, Irv4, Irv5, Irv6, dan Irv7, ditransfer secara terpisah ke TSA miring sebagai media stok dan disimpan pada $4^{\circ} \mathrm{C}$ untuk penggunaan lebih lanjut.

\section{Persiapan Kultur Bakteri}

Sepuluh mikroliter dari isolat yang diperoleh ditransfer ke tabung reaksi yang berisi $50 \mathrm{~mL}$ media TSB. Isolat ditumbuhkan pada media tersebut selama 24 jam pada suhu $37^{\circ} \mathrm{C}$. Selanjutnya dilakukan proses sentrifugasi untuk memperoleh supernatant dengan kecepatan 6000 rpm selama 20 menit. Supernatan yang diperoleh, disimpan pada suhu $-20^{\circ} \mathrm{C}$ dan diukur aktivitas antibakterinya.

Aktivitas Bakteri Endofit Daun Cengkeh (Syzigium aromaticum L) terhadap Bakteri Staphylococcus aureus dan Escherichia coli

Pengujian aktivitas antibakteri isolat bakteri endofit daun cengkeh (Syzygium aromaticum L) terhadap Staphylococcus aureus ATCC 6538 dan Escherichia coli ATCC 8739 dilakukan dengan metode paper disk pada media Tryptone Soy Agar (TSA). Lima kertas cakram disiapkan yaitu masing-masing tiga kertas cakram untuk bakteri endofit daun cengkeh dan dua kertas cakram untuk kontrol positif dan kontrol negatif. Selanjutnya diuji bakteri endofit potensial menggunakan metode fraksinasi dengan pelarut n-butanol, n-heksana, dan etil asetat.

\section{Optimasi Kurva Pertumbuhan}

Isolat potensial ditumbuhkan dalam medium TSB $5 \mathrm{~mL}$ kemudian diinkubasi selama 12 jam. Isolat potensial ditumbuhkan pada media TSB sebanyak $50 \mathrm{~mL}$, diambil $1 \%$ kemudian dikultur isolat potensial tersebut pada suhu $37^{\circ} \mathrm{C}$ selama 24 jam dilakukan proses inkubasi, setiap dua jam kultur isolat diambil dan disimpan pada suhu $20^{\circ} \mathrm{C}$. Kultur hasil isolasi selanjutnya dilakukan penentuan nilai serapannya pada panjang gelombang $600 \mathrm{~nm}$ kemudian dibuat kurva pertumbuhannya.

\section{Uji Konsentrasi Hambat Minimum (KHM)}

Supernatan Bakteri endofit potensial daun dilakukan pengenceran terlebih dahulu dengan konsentrasi 5\%, 10\%, 15\%, 20\%, dan $25 \%$. Kemampuan supernatan menghambat pertumbuhan Staphylococcus aureus ATCC 6538 dan Escherichia coli ATCC 8739 ditentukan berdasarkan zona hambat.

\section{Analisis Senyawa Metabolit Sekunder dengan Gas Chromatography-Mass Spectrometer (GCMS)}

Analisis kimia dilakukan dengan menggunakan kromatografi gas ditambah dengan GCMS Agilent Technologies 7890 dilengkapi dengan HP ultra 2 Capillary Column $(30 \mathrm{~m} \times 0.20$ mmLD, $\quad 0.11 \mu \mathrm{m}$ filmthickness). Temperatur kolom, $250^{\circ} \mathrm{C}$, kecepatan linear gas helium gas pembawa, $30 \mathrm{~cm} /$ detik, rasio split, $1 / 30$, temperatur sumber ion, $230^{\circ} \mathrm{C}$, dan temperatur antarmuka $280^{\circ} \mathrm{C}$. Identifikasi senyawa kimia dibandingkan dengan database dan dikonfirmasi menggunakan sampel standar otentik (Suhendar \& Sogandi, 2019).

\section{Identifikasi Molekuler Bakteri Endofit Daun Cengkeh (Syzigium aromaticum L) (Suhendar et al., 2021)}

Dari total tujuh isolat, isolat potensial selanjutnya dilakukan isolasi genom. Selanjutnya dilakukan amplifikasi menggunakan gen $16 \mathrm{~S}$ rRNA menggunakan mesin PCR. Hasil PCR selanjutnya dilakukan elektroforesis menggunakan gel agarose dan dilakukan visualisasi dibawah sinar UV dan diperoleh pita DNA, berikutnya dilakukan pemurnian. Selanjutnya dilakukan pensejajaran dengan urutan basa dalam database NCBI. Hasil pensejajaran selanjutnya dimasukkan ke dalam NJPlot untuk dilakukan konstruksi pohon filogenetik. 


\section{HASIL DAN PEMBAHASAN}

Tujuh isolat murni (Irv1, Irv2, Irv3, Irv4, Irv5, Irv6, Irv7) diperoleh dari bakteri endofit daun cengkeh (Syzygium aromaticum L). Pertama pengujian dilakukan dari tujuh isolat murni, yaitu pengujian akivitas antibakteri dari isolat bakteri daun cengkeh (Syzygium aromaticum L) terhadap bakteri staphylococcus aureus di 6538 Escherichia coli ATCC 8739. Uji aktivitas bakteri endofit daun cengkeh (Syzygium aromaticum L) terhadap Staphylococcus aureus ATCC 6538 dan Escherichia coli ATCC 8739 dilakukan dengan metode paper disk dengan menggunakan media TSA. Pada pengujian menggunakan lima kertas cakram pada setiap bakteri yang diuji. Tiga cakram untuk sampel bakteri endofit daun cengkeh dan dua cakram untuk kontrol positif dan kontrol negatif .

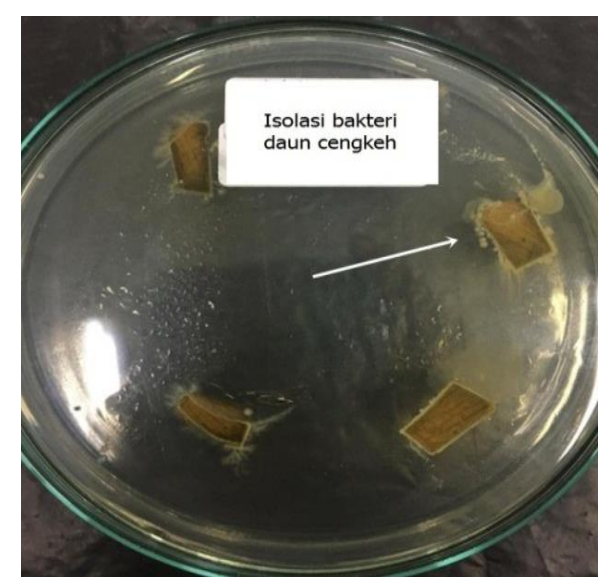

Gambar 1. Hasil isolasi bakteri endofit daun cengkeh (Syzygium aromaticum $\mathrm{L}$ )

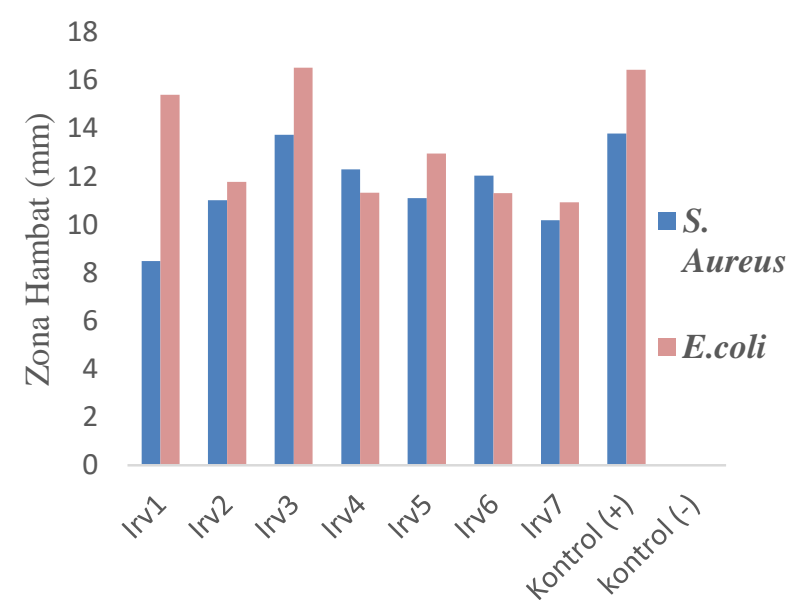

Gambar 2. Diagram Hasil Uji Aktivitas Bakteri Endofit daun cengkeh (Syzygium aromaticum $\mathrm{L}$ )
Hasil tes bakteri endofit potensial daun cengkeh (Syzygium aromaticum L), kontrol negatif dalam pelarut dan kontrol positif dalam bentuk ampisilin $10 \mathrm{mg} / \mathrm{ml}$ menunjukkan bahwa bakteri endofit Irv3 memiliki penghambatan yang lebih signifikan daripada isolat lainnya. Oleh karena itu sampel Irv3 disebut sebagai bakteri endofit potensial. Tes awal bakteri endofit potensial Irv3 dilakukan dengan menggunakan metode fraksinasi dengan pelarut n-butanol, n-heksana dan etil asetat.

Tabel 1. Hasil uji aktivitas terhadap bakteri endofit Irv3

\begin{tabular}{cc}
\hline Bakteri Potensial & Diameter rataan $(\mathrm{mm})$ \\
\hline Kontrol $(-)$ & 0 \\
kontrol $(+)$ & $16,42 \pm 0,03$ \\
n-butanol & $11,88 \pm 0,52$ \\
n-heksan & $17,16 \pm 0,97$ \\
etil asetat & $20,65 \pm 2,49$ \\
\hline
\end{tabular}

Hasil aktivitas uji bakteri endofit potensial daun cengkeh Irv3 dengan kelompok uji fraksi n-butanol, fraksi n-heksana dan fraksi etil asetat menunjukkan angka daya penghambatan terbaik adalah fraksi etil asetat dengan luas rata-rata zona hambar di kedua bakteri uji adalah 20,65 $\pm 2,49$. Berdasarkan hasil kurva yang terbentuk pada gambar 3, dapat diketahui bahwa potensi bakteri endofit Irv3 mengalami fase lag atau fase adaptasi pada jam ke-0 hingga ke-12; hal ini dapat dilihat dari peningkatan absorbansi yang tidak terlalu tinggi. Pada fase ini bakteri melakukan penyesuaian terhadap media tumbuh bakteri. Pada fase ini bakteri mampu atau tidak mampu untuk bertahan hidup pada media tersebut. Setelah mengalami fase lag, bakteri potensial mengalami fase eksponensial yang dapat dilihat dengan peningkatan nilai absorbansi pada jam ke-14 hingga ke-20. Pada fase ini, tentu bakteri yang mampu bertahan hidup pada media tumbuh akan tumbuh dengan cepat. Pertumbuhan bakteri tersebut antara bakteri, memiliki pertumbuhan yang berbeda-beda, hal ini dipengaruhi oleh faktor sifat genetik dari bakteri tersebut. Setelah itu, bakteri potensial menjalani fase stasioner yang dapat dilihat pada nilai absorbansi pada jam ke-20 hingga ke-26. Pada fase ini, bakteri menuju laju kematiannya. Kondisi ini menunjukkan keseimbangan keseluruhan bakteri dengan kondisi media dan adanya pembelahan sel yang berkurang. 


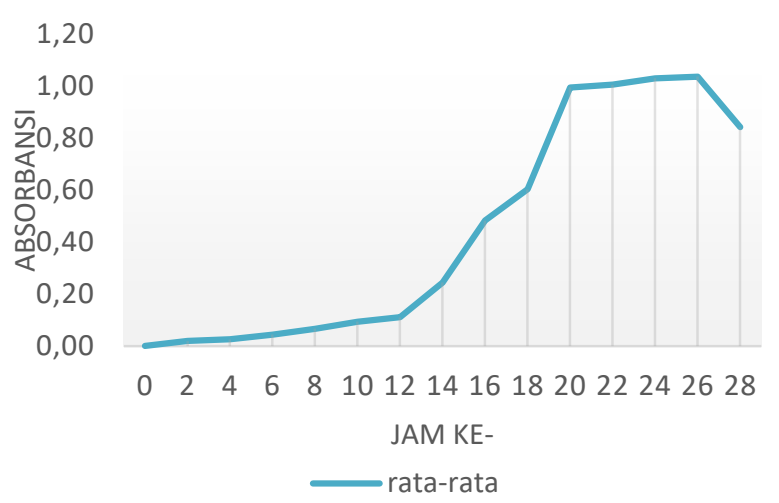

Gambar 3. Hasil optimasi kurva pertumbuhan

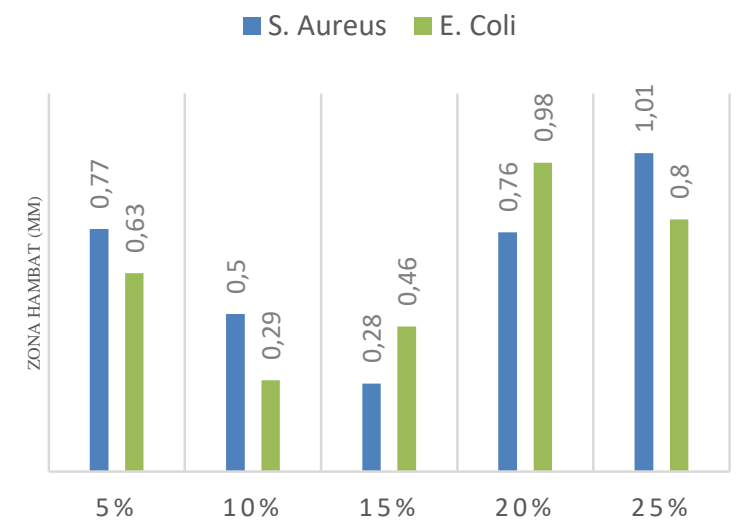

Gambar 4. Hasil Uji Konsentrasi Hambat Minimum

Bakteri endofit potensial Irv3 pada fraksi etil asetat dianggap $100 \%$ dilakukan pengenceran terlebih dahulu dengan konsentrasi 5\%, 10\%, $15 \%$, 20\%, dan 25\%.. Hasil tes aktivitas antibakteri dari lima konsentrasi ini menunjukkan bahwa setiap konsentrasi menghasilkan zona hambat terhadap Staphylococcus aureus dengan rata-rata $0,77 \pm 0 \mathrm{~mm} ; 0,50 \pm 0,002 \mathrm{~mm} ; 0,28$ $\pm 0,002 \mathrm{~mm} ; 0,76 \pm 0,01 \mathrm{~mm}$ dan $1,01 \pm 0 \mathrm{~mm}$. Sedangkan zona resistance terhadap Escherichia coli dengan rata-rata $0,63 \pm 0 \mathrm{~mm} ; 0,29 \pm 0 \mathrm{~mm}$; $0,46 \pm 0,01 \mathrm{~mm} ; 0,98 \pm 0,002 \mathrm{~mm}$; dan $0,80 \pm$ $0,001 \mathrm{~mm}$. Hasil pengukuran Konsentrasi Hambat Minimum (KHM) kemudian dihitung untuk menunjukkan bahwa konsentrasi terendah yang menghasilkan zona hambar adalah $15 \%$ pada bakteri Staphylococcus aureus. Pada bakteri Escherichia coli, konsentrasi terendah adalah 10 Hasil kedua konsentrasi tersebut ditandai dengan tidak adanya keruhan sebelum inkubasi dan sesudah inkubasi.

Gambar 5 dan 6 menunjukkan terjadinya peningkatan absorbansi dari supernatan sel, yang menandakan terjadinya peningkatan bahan-bahan yang dapat diserap pada panjang gelombang 260 $\mathrm{nm}$ dan $280 \mathrm{~nm}$ yang di keluarkan oleh sel bakteri.
Pada pengujian ini terlihat adanya kebocoran sel yang diamati pada panjang gelombang $260 \mathrm{~nm}$ untuk protein dan panjang gelombang $280 \mathrm{~nm}$ untuk asam nukleat. Kebocoran sel dapat diakibatkan adanya senyawa aktif yang dihasilkan oleh bakteri endofit. Dengan adanya senyawa kimia tersebut dapat mengakibatkan perubahan permeabilitas membran sel sehingga komponen didalam sel terganggu dan mengakibatkan komponen sel keluar.

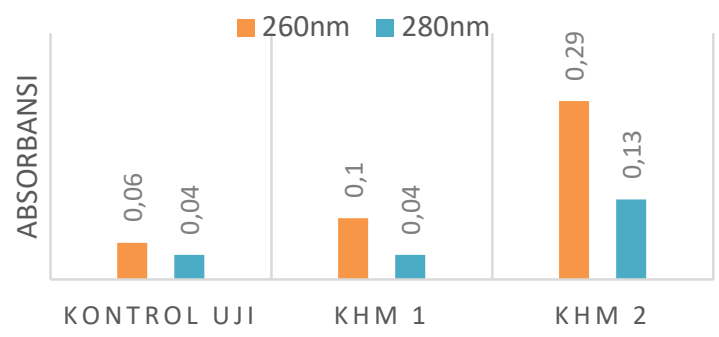

Gambar 5. Kebocoran Sel Protein dan Asam Nukleat daun cengkeh terhadap bakteri Staphylococcus aureus ATCC 6538.

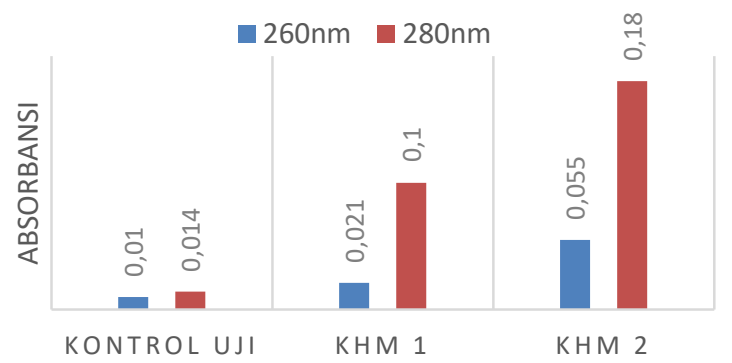

Gambar 6. Kebocoran Sel Protein dan Asam Nukleat daun cengkeh terhadap bakteri Escherichia coli ATCC 8739.

Staphylococcus aureus ATCC 6538 memiliki kebocoran sel paling banyak daripada Escherichia coli ATCC 8739. Konsentrasi bakteri potensial dari fraksi daun cengkeh etil asetit Irv3 mempengaruhi kebocoran asam nukleat dan protein dalam sel bakteri, yaitu pada konsentrasi 2 MIC, ada kebocoran asam nukleat daripada pada konsentrasi 1 MIC. Bakteri Staphylococcus aureus ATCC 6538 paling sensitif terhadap bakteri endofitik potensial Irv3 etil asetat daun cengkeh (Nilai MIC 15\%) dibandingkan dengan Escherichia coli ATCC 8739 (nilai MIC 10\%). Perbedaan antara keduanya adalah karena perbedaan dalam struktur dinding sel,dimana bakteri Gram-positif memiliki lapisan lipopolysaccharide tipis dan lapisan peptidoglikan tebal. Bakteri gram negatif 
memiliki lapisan lipopolysaccharide tebal dan lapisan peptidoglikan tipis.

Senyawa yang diidentifikasi ini tidak semuanya termasuk dalam kelompok senyawa dengan aktivitas antibakteri. Senyawa dengan konsentrasi tertinggi adalah benzylhexahydropyrrolo [1,2-a] pyrazine-1,4dione, dengan kandungan $13,47 \%$ pada waktu retensi 31.330. Senyawa dominan yang paling sering terdeteksi dalam analisis GCMS ini adalah Pyrazine dan turunannya terdeteksi pada waktu retensi 28.841 (2,52\%), 29.027 (5,04\%), 29.206 $(11,73 \%)$, dan $31.303(12,58 \%)$. Piran adalah senyawa dengan komponen heterosiklik yang mengandung nitrogen dan hasil dari interaksi antara dikarbonil, sedangkan amina adalah interaksi antara kelompok asam amino. Peran rantai asam amino dalam membentuk pyrazine sangat penting,terutama bagian dari rantai yang mengandung atom nitrogen seperti glutamin, asparagon,dan lysine (Yulia \&Wijaya, 2015). Pyrazine termasuk dalam senyawa alkaloid karena memiliki atom nitrogen. Senyawa alkaloid dalam isolat Irv3 dianggap memiliki aktivitas antibakteri.

Kemurnian DNA dapat dilihat dari rasio absorbansi DNA $\left(\mathrm{A}_{260} / \mathrm{A}_{280}\right)$, di mana kemurnian DNA yang diperoleh dari studi isolat Irv3 adalah 1,85 yang menurut Sambrook et al. (1989), hasil isolasi DNA dikatakan murni jika nilai rasio $\mathrm{A}_{260}$ $\mathrm{A}_{280}$ adalah antara 1,8-2,00. Dalam penelitian ini, konsentrasi DNA yang diekstraksi adalah 283,1 ng / ul. Setelah pemurnian, urutan gen rRNA 16S ditentukan. Urutan parsial rRNA 16S yang diperoleh selaras dengan urutan basis dalam database NCBI. Urutan isolat Irv3 yang selaras menunjukkan bahwa gen rRNA 16s dalam isolat \pm 1500 bp (pasangan basa). Selanjutnya, urutan gen rRNA 16s dari isolat Irv3 terdaftar ke database NCBI Genbank sebagai Staphylococcus epidermidis. Rekonstruksi pohon filogenetik mendukung mencari tahu hubungan antara spesies (Zhang et al., 2019). Penyelarasan urutan bakteri dengan beberapa urutan bakteri lain yang diambil dari database NCBI GenBank dilakukan dengan menggunakan cluster X2. Selain itu, hasil penyelarasan dimasukkan ke dalam NJPlot untuk merekonstruksi pohon filogenetik. Rekonstruksi pohon filogenetik menunjukkan bahwa isolat Irv3 memiliki hubungan terdekat dengan Staphylococcus epidermidis yang mengidentifikasi kesamaan $100 \%$. Cladogram menghasilkan urutan 16s rRNA dari isolat potensial Irv3 dan nota sekutunya.

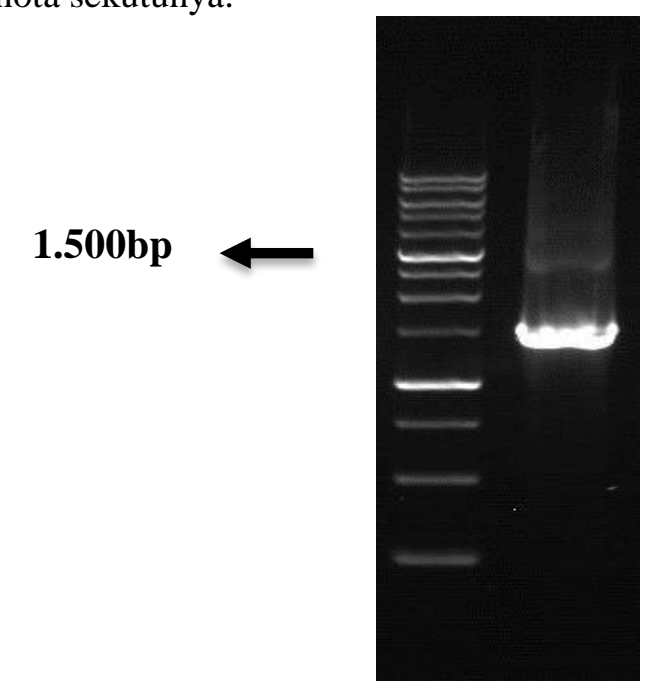

Gambar 8. Hasil elektroforesis dari produk amplifikasi gen 16S-rRNA

Hasil elektroforesis sampel diketahui memiliki pita yang disajikan dan sejajar dengan penanda sekitar 1.500 bp. Hal ini menunjukkan bahwa fragmen gen terlibat dengan ukuran \pm $1.500 \mathrm{bp}$, sehingga disimpulkan bahwa proses penguatan isolat Irv3 berhasil dilakukan. Kemudian isolat Irv3 ditentukan menggunakan urutan 16S-rRNA yang dianalisis secara penuh pada analisis Cluster Malaysia basis $1^{\text {st }}$ pada urutan dilakukan dengan program BLAST-IN dari NBCI.

Tabel 1. Hasil GCMS Isolat Bakteri Endofit Potensial (Irv3)

\begin{tabular}{cccc}
\hline $\begin{array}{c}\text { Jenis/Kode } \\
\text { Sampel }\end{array}$ & RT & Senyawa & $\begin{array}{c}\text { Kandungan } \\
(\%)\end{array}$ \\
\hline & 28.841 & Pyrrolo [1,2-a] pyrazine-1,4-dione hexahydro-3-( 2-methyl propyl)- & 2,52 \\
& 29.027 & ISOBUTYLHEXAHYDROPYRROLO [1,2-A] PYRAZINE-1,4-DIONE & 5,04 \\
Isolated & 29.206 & Pyrrolo [1,2-a] pyrazine-1,4-dione hexahydro-3-( 2-methylpropyl)- & 11,73 \\
Irv3 & 31.303 & Pyrrolo [1,2-a] pyrazine-1,4-dione hexahydro-3-( phenylmethyl)- & 12,58 \\
& 31.330 & BENZYLHEXAHYDROPYRROLO [1,2-A] PYRAZINE-1,4-dione & 13,47 \\
\hline
\end{tabular}


Tabel 2. Hasil Pengukuran Konsentrasi DNA

\begin{tabular}{cccc}
\hline \multirow{2}{*}{ Nama Sample } & \multicolumn{2}{c}{ Panjang Gelombang (A) } & \multirow{2}{*}{ Konsentrasi (ng/ul) } \\
& $260 / 280$ & $260 / 230$ & 283.1 \\
\hline Irv 3 & 1.85 & 2.27 & \\
\hline
\end{tabular}

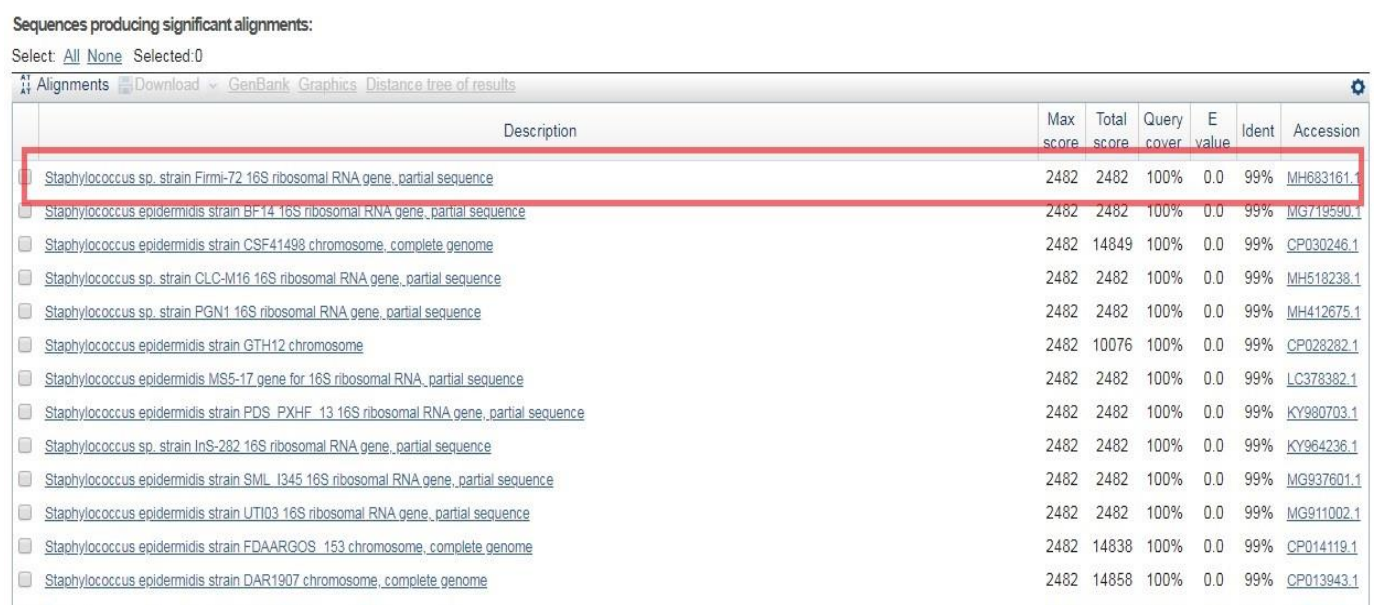

Gambar 9. Hasil Analisi BLAST dari Isolat Irv3

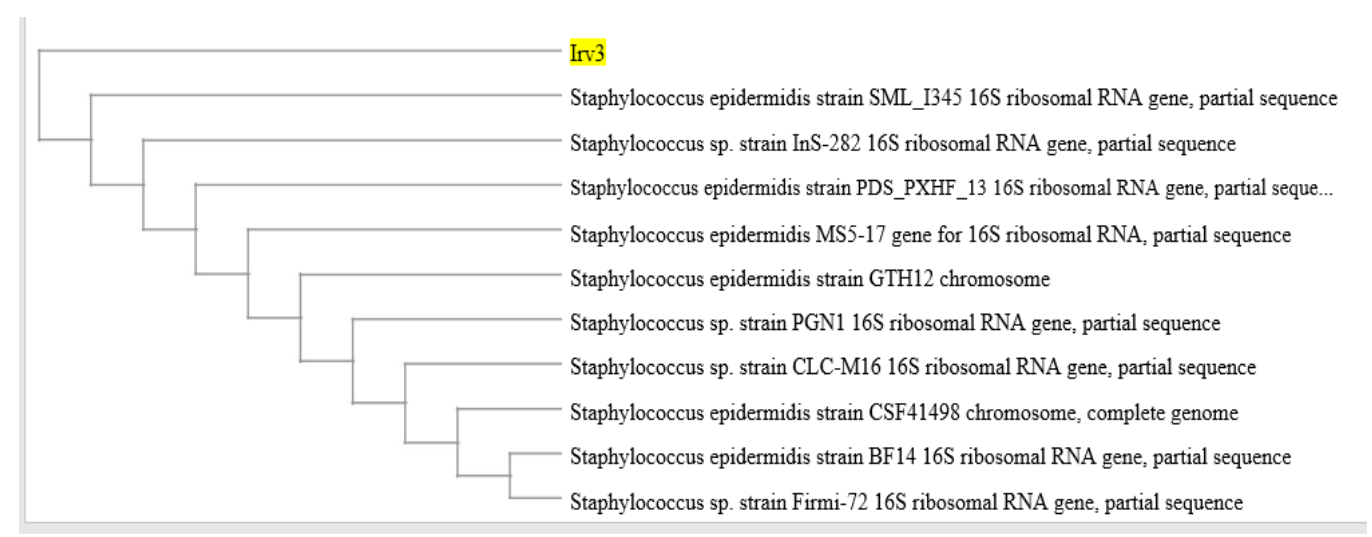

Gambar 10. Phylogenetic tree dari Isolat Irv3

Hasil analisa dengan menggunakan program BLAST menunjukan bahwa bakteri endofit potensial isolat Irv3 merupakan bakteri dengan spesies Staphylococcus sp. dengan identity 99\% terhadap strain Firmi-72. Filogenetik adalah metode yang digunakan dalam sistematika untuk menunjukkan keanekaragaman suatu organisme dengan melalui proses penataan ulang hubungan kekerabatan. Pohon filogenetik merupakan suatu grafik yang ditampilkan yang mampu memberikan gambaran kekerabatan yang terdiri dari sejumlah titik-titik dan beberapa cabang dengan hanya satu cabang yang menghubungkan dua titik terdekat. Setiap titik merupakan wakil unit suatu taksonomi dan setiap cabang merupakan wakil yang memiliki hubungan antar unit dengan memberikan gambaran hubungan turun temurun terhadap nenek moyang.
Hasil analisis pohon filogenetik isolat Irv3 menunjukkan kekerabatan yang lebih dekat dengan spesies bakteri Staphylococcus sp, sehingga isolat Irv3 diidentifikasi menggunakan rRNA 16s. Staphylococcus adalah bakteri Grampositif dengan diameter $0,5-1,5 \mu \mathrm{m}$ dan ditandai oleh lokus individu, yang membagi lebih dari satu bidang menjadi kelompok-kelompok. Staphylococcus adalah anaerobik fakultatif nonmotil, tidak membentuk spora yang tumbuh dengan respirasi aerobik atau fermentasi. Sebagian besar spesies memiliki kebutuhan nutrisi yang relatif kompleks, tetapi, secara umum, mereka membutuhkan sumber nitrogen organik, dipasok oleh 5 hingga 12 asam amino esensial, misalnya arginin, valin, dan vitamin B, termasuk tiamin dan nikotinamida (Khianngam et al., 2013). Selain metabolit sekunder yang aktif secara biologis, bakteri endofit juga menghasilkan 
antimikroba penting. Dalam sebuah penelitian yang mencari enzim endofit berproduksi tinggi di bakau di Thailand, Khianngam et al. (2013) menemukan bahwa bakteri Gram-positif menunjukkan lebih banyak aktivitas hidrolitik daripada bakteri Gram-negatif. Tanpa diduga, strain spesifik $S$. epidermidis diamati untuk menghasilkan analog nukleobase dengan kapasitas untuk menghambat sintesis DNA. Ketika diberikan secara intravena atau diterapkan pada tikus, molekul ini atau strain $S$. epidermidis yang hidup itu sendiri menekan pertumbuhan tumor in vivo (Nakatsuji et al., 2018). Selanjutnya, Nawangsih et al, (2011) melaporkan bahwa bakteri endofit $S$. epidermidis adalah pengendali biologis bakteri patogen lain (Ralstonia solanacearum) dalam tomat.

\section{KESIMPULAN}

Kesimpulan pada penelitian ini adalah terdapat tuujuh isolat murni bakteri endofit daun cengkeh yang diperoleh dari fraksi etil asetat daun cengkeh terhadap pertumbuhan bakteri Staphylococcus aureus ATCC 6538 (15\%) dengan zona hambat pertumbuhan bakteri sebesar $0.28 \pm 0,002 \mathrm{~mm}$ dan bakteri Escherichia coli ATCC 8739 (10\%) dengan zona hambat $0.29 \pm 0$ $\mathrm{mm}$. Optimasi Kurva pertumbuhan bakteri potensial Irv3 mengalami tiga ase yaitu fase lag atau fase adaptasi, fase eksponensial dan fase stasioner. Pada jam ke-18 bakteri potensial Irv3 memproduksi metabolit sekunder. Isolat Irv3 mengandung senyawa pyrazine yang dapat digunakan sebagai sumber bahan alam untuk kesehatan dan teridentifikasi sebagai bakteri Staphyllococcus sp.

\section{SARAN}

Adapun saran dari penelitian ini adalah isolat potensial Irv3 dapat dilakukan pengujian berbagai bioaktivitas lainnya serta dilakukan isolasi senyawa kimia dari isolat potensial Irv3.

\section{UCAPAN TERIMA KASIH}

Penulis ingin mengucapkan terima kasih kepada Fakultas Farmasi Universitas 17 Agustus 1945, Jakarta, Indonesia, yang telah menyediakan fasilitas yang diperlukan untuk melaksanakan penelitian ini.

\section{DAFTAR PUSTAKA}

Asif, M. (2015). Chemistry and antioxidant activity of plants containing some phenolic compounds. International Scientific Organization. Journal, 1(1), 35-52.

Barbara, J. E. S.,\& Christine, J. C. B. (2006). What are endophytes International Microbial Root Endophytes? (Thomas N. Sieber). Springer-Verlag, Berlin.

Barthwal, J., Nair, S., \& Kakkar, P. (2008). Heavy metal accumulation in medicinal plants collected from environmentally different sites. Biomedical Environmental Science, 21, 319-324.

Birch, A. E., Fenner, G. P., Watkins, R., \& Boyd, L. C. (2001). Antioxidant properties of evening primrose seed extracts. Journal Agriculture Food Chemistry, 49, 45024507.

Candrawati, M.K. (2018). Pengaruh Pemberian Ekstrak Etanol 70\% Biji Rambutan (Nephelium lappaceum L) terhadap Kualitas Sperma Mencit (Mus muscullus L) yang Di Induksi Streptozotocin (Skripsi). Universitas Negeri Malang.

Jassim, SA \& Naji, MA. (2003). Novel antiviral agents: a medicinal plant perspective. Journal of Applied Microbiology. 95(3), 412-27. doi: 10.1046/j.13652672.2003.02026.x. PMID: 12911688.

Khianngam, S., Yupa, P., Taweesak, T., Somboon, T. (2014). Screening and identification of cellulase producing bacteria isolated from oil palm meal. Journal of Applied Pharmaceutical Science. 4 (04), 090-096.

Larran, S., Simon, M. R., Moreno, M. V., Siurana, M. P. S., \& Perello, A. (2016). Endophytes from wheat as biocontrol agents against tan spot disease. Biological Control, 92,17-23.

Nawangsih AA, Damayanti I, Wiyono S, Kartika J.G. (2011). Selection and Characterization 
of endophytic bacteria as biological control agents of tomato bacteria wilt disease. Hayati. 18(1),66-70. DOI: http://dx.doi.org/10.4308/hjb.18.2.66.

Radji, M. (2005). Peranan bioteknologi dan mikroba endofit dalam pengembangan obat herbal. 113-126.

Sogandi, \& Nilasari, P. (2019). Isolation and molecular identification of Endophytic bacteria from Noni fruits (Morinda citrifolia 1.) and their antibacterial activity. IOP Conference Series: Earth Environmental Science, 299, 012020.

Sogandi, S., Mustofa, A. Z., Artika, I. M., \& Bugi, R. B. (2015). Inhibitory activity of Lactobacillus Plantarum U10 isolated from tempoyak (fermented durian) made in Indonesia against Salmonella typhi. Microbiology Indonesia, 9(2), 73-81. doi:10.5454/mi.9.2.4.

Sogandi., Mustofa, A. Z., \& I Made, A. (2019). The characterisation of bacteriocins produced by Lactobacillus Plantarum strains isolated from traditional fermented foods in Indonesia and the detection of its plantaricinen coding genes. Indonesian Journal of Biotechnology, 24(1),1-7. Diperoleh dari doi: 10.22146/ijbiotech.42582.

Stanbury, P., Whitaker, A., \& Hall, S. (2016). Principles of fermentation technology. Third Edition. Butterworth Heinemann, Oxford.

Suhendar, U., Siti, M., Sogandi. (2021). Identification Of Molecular Bacterial Isolate Endofit Bacteria Kasturi Mango (Mangifera Casturi Kosterm) Leaves And Analysis Of Antibacterial Activity (In Indonesian). Sains Natural: Jurnal Ilmiah Ilmu-Ilmu Biologi dan Kimia. 11(1).

Suhendar, U, \& Sogandi, S. (2019). Identification of bioactive compounds in clove leaves (Syzygium aromaticum) extract inhibits streptococcus mutants (In Indonesian). $\mathrm{Al}$ kauniyah: Jurnal Biologi, 12(2), 229-239. doi:10.15408/kauniyahv12i2.12251.
Syarmalina. (2008). Endofit dan Pelestarian Alam. PT. ISFI Medisina.

Tamura, K., Peterson, D., Peterson, N., Stecher, G., Nei, M., \& Ku-mar. (2011). MEGA 5: Molecular evolutionary genetics analysis using maximum likelihood, evolutionary distance, and maximum parsimony methods. Molecular Biology Evolution, 28(10), 2731-2739. doi:10.1093/molbev/msr121.

Tanaka M, Sukiman H,Takebayashi M, Saito K, SutoM, Prana MS, dan Tomita F. (1999). Isolation, Screening and Phylogenetic Identification of Endophytes from Plants in Hokaido Japan and Java Indonesia. Microbes and Environment 14(4), 237241.

Wang, P., Kong, F., Wei, J., Wang, Y., Wang, W., Hong, K., \& Zhu, W. (2014). Alkaloids from the mangrove-derived actinomycetes Jishengella endophytic 161111. MarineDrugs, 12(1), 477-490. doi:10.3390/md12010477.5.21982208.2002.

Yulia, R., \& Wijaya, I. S. (2015). Antioxidant compounds of methanolic extract of soybean (Glycine $\max$ (L) Merill)detam one variety from ultrasound extraction method(In Indonesian).Jurnal Sains Farmasi \& Klinis,2(1), 1-10. doi: 10.29208/jsfk.2015.2.1.57.

Zhang, Y., Yuan, Y., Pang, Y., Yu, F., Yuan, C., Wang, D., Hu, X. (2019). Phylogenetic reconstruction and divergence time estimation of blue dc. (Asteraceae: inuleae) in China based on nrDNA ITS and cpDNA trnL-F sequences. Plants, 8(210), 1-19. doi:10.3390/plants8070210.

Zinniel, D. K., Lambrecht, P., Harris, B. N., Feng, Z., Kuczmarski, D., Higley, P., Ishimaru, C. A., Arunakumari, A., Barletta, R. G., \& Vidaver, A. K. (2002). Isolation and characterisation ofen-endophytic colonising bacteria from agronomic crops and prairie plants. Applied and Environmental Microbiology, 68(5), 21982208. doi:10.1128/aem.68.5.21982208.2002 . 